\title{
Medical and legal problems in the treatment of delinquent girls in Scotland II. Sexually transmitted disease in girls in custodial institutions
}

\author{
D. H. H. ROBERTSON AND G. GEORGE \\ From the Department of Venereology, Edinburgh Royal Infirmary
}

Keep strict watch over a headstrong daughter, lest, when she finds liberty, she use it to her hurt Ecclesiasticus, xxvi, 10.

IN an earlier paper (Robertson, 1969), the Scottish legal procedure and proposals for dealing with juvenile delinquents, particularly females, were described and it was shown that very few of those against whom a charge was proved in a court were committed to custodial institutions such as remand homes and approved schools. Some girls committed to such institutions are those dealt with under criminal proceedings but most lose their liberty through the application of the civil processes of the Children and Young Persons (Scotland) Act, 1937. Though promiscuity is common among young females dealt with by the courts, it is only those reaching custodial institutions who are likely to receive the special medical attention necessary for the detection or exclusion of venereal disease. This paper reviews the results of such examinations of girls at two approved schools and a remand home, obtained over a period of several years. Relevant statutory regulations applicable to the medical examination of those committed to remand homes and approved schools have been collected and data on the policy of examining these girls are presented.

\section{Variations in the policy of requesting examination for the exclusion of venereal disease}

The Figure (opposite) shows the variations in the proportions of girls attending the clinic from a remand home and from two approved schools (A and $\mathrm{C}$ ). In one approved school (A) referral for examination has become virtually a routine on

Received for publication March 20, 1969.

This paper includes the data presented at Edinburgh at a meeting of the Scottish Branch of the Medical Society for the Study of Venereal Diseases on March 2, 1968. admission to the institution or on return to school after absconding, after a holiday at home, or after recall to the school for other reasons. In the other school (C) girls are sent to the clinic only after a discussion of the matter between the girl and the headmaster and they are encouraged to attend when they recognize the necessity and reason for the examination. At the remand home an alteration in policy has brought about a decrease in the proportion of girls sent for examination.

\section{Results of examinations for the exclusion of sexually-transmitted disease in girls from custodial institutions}

The wide variation in the use of the clinic by these three institutions is illustrated in the Figure and by the data in Table I, and the results of examinations undertaken to exclude venereal disease are given in Tables II, III, and IV (overleaf).

TABLE I Attendances at clinic by girls (14 to under 17 years of age) admitted to approved schools $A$ and $C$ and to the remand home

\begin{tabular}{|c|c|c|c|c|}
\hline Institution & Year & $\begin{array}{l}\text { No. of } \\
\text { girls } \\
\text { admitted }\end{array}$ & $\begin{array}{l}\text { No. of } \\
\text { visits } \\
\text { to } \\
\text { clinic }\end{array}$ & $\begin{array}{l}\text { Visits to } \\
\text { clinic per } \\
\text { admission } \\
\text { to school } \\
\text { or remand } \\
\text { home }\end{array}$ \\
\hline Approved school A & $\begin{array}{l}1964 \\
1965 \\
1966\end{array}$ & $\begin{array}{l}35^{\star} \\
37^{\star} \\
29 \star\end{array}$ & $\begin{array}{l}248 \\
257 \\
189\end{array}$ & $\begin{array}{l}7 \cdot 1 \\
6 \cdot 9 \\
6 \cdot 5\end{array}$ \\
\hline Approved school C & $\begin{array}{l}1964 \\
1965 \\
1966\end{array}$ & $\begin{array}{l}20 \star \\
10^{\star} \\
18^{\star}\end{array}$ & $\begin{array}{l}64 \\
15 \\
51\end{array}$ & $\begin{array}{l}3 \cdot 2 \\
1.5 \\
2 \cdot 8\end{array}$ \\
\hline Remand home & 1965 & 95 & 142 & 1.5 \\
\hline
\end{tabular}

*The results for the 12 months ending March 31 of the subsequent year.

All other 12-month results are for calendar years. 

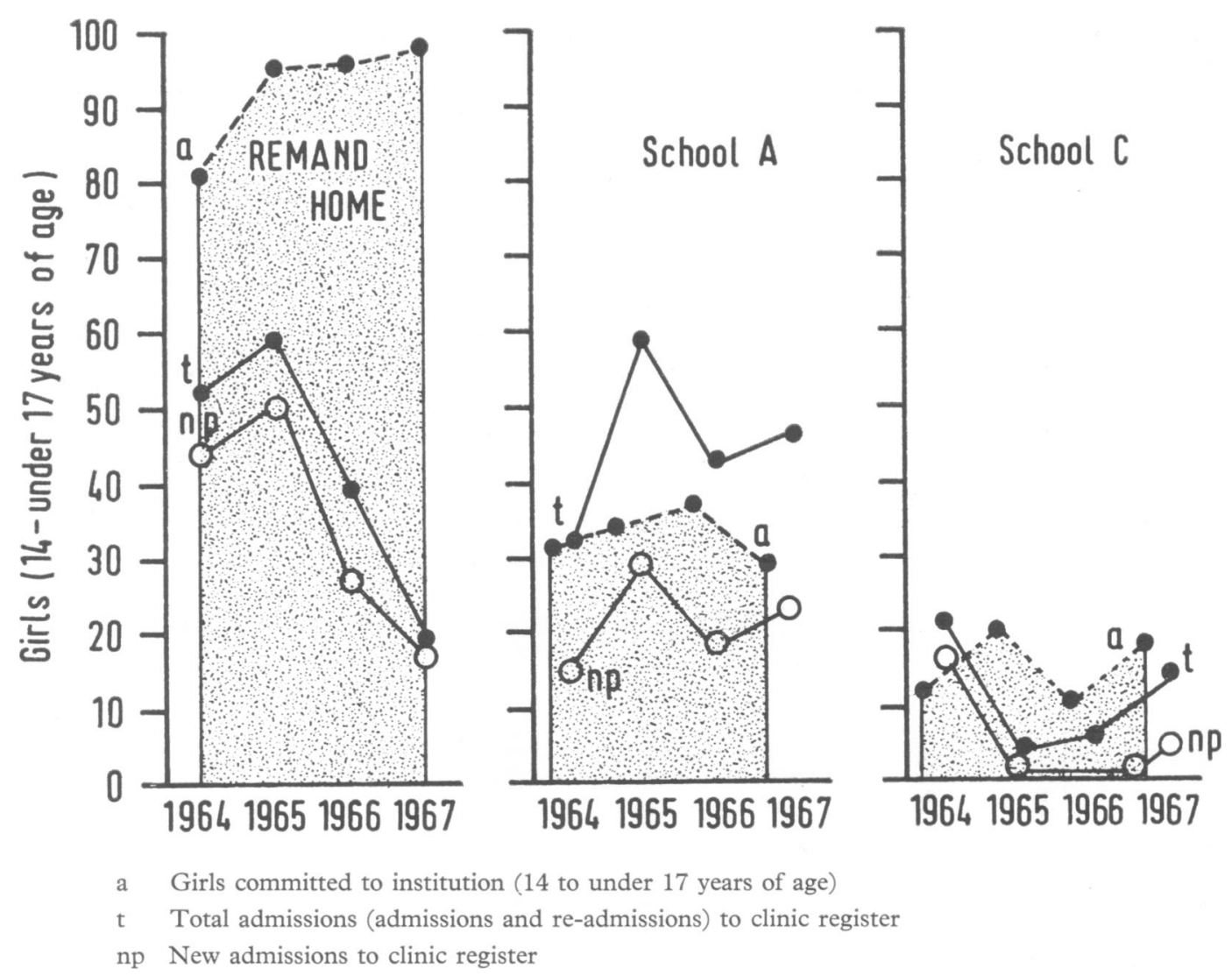

FIGURE Variation in attendance of girls at a clinic for examination for the exclusion of sexually-transmitted disease. In the Remand Home there has been a sharp diminution in the numbers sent. In School ' $A$ ' a high proportion of the girls are seen on admission and again on re-admission after absconding or after recall from leave

A vaginal examination by speculum was omitted only in girls found to be virgo intacta. Culture of urethral and cervical material for Neisseria gonorrhoeae was always undertaken at the first examination on admission of the girl to the clinic register or after re-admission when she returned to the institution after absconding, after a holiday, or for other reasons. $\mathrm{Re}$-examinations included microscopic examination of urethral and cervical smears which were repeated when possible during a follow-up period of up to 3 months since the last intercourse. Serological tests for syphilis were also carried out during the follow-up period.

Of 110 girls examined on first referral to the clinic from approved schools (Tables II and III), only two ( 1.8 per cent.) had gonorrhoea proven by culture, but 26 (23.6 per cent.) had vaginal trichomoniasis, nine had phthirus pubis, and three had genital warts. Of 54 re-examined after returning to the school, four ( 7.4 per cent.) had proven gonorrhoea, and twelve (22.2 per cent.) trichomoniasis. Of eighteen recalled for the third time, three (16.7 per cent.) had gonorrhoea and six trichomoniasis (33.3 per cent.). The apparently increasing incidence of gonorrhoea in those re-admitted is explained by the higher proportion of promiscuous girls among habitual absconders.

Of the nine cases of gonorrhoea proven by culture all were detected at the first examination or after recall. In five cases the films showed characteristic diplococci, in three they were doubtful, and in one they were negative. The multiple re-examinations (given as number of visits in Tables II, III, and IV) were carried out as tests of cure and as re-examina- 
TABLE II Results of examinations of girls sent to clinic from approved school A (November 1963December 1966)

\begin{tabular}{|c|c|c|c|c|c|c|c|c|c|c|c|}
\hline \multirow[b]{2}{*}{$\begin{array}{l}\text { Admission } \\
\text { to clinic }\end{array}$} & \multirow[b]{2}{*}{$\begin{array}{l}\text { Age } \\
\text { (yrs) }\end{array}$} & \multirow[b]{2}{*}{$\begin{array}{l}\text { No. of } \\
\text { girls }\end{array}$} & \multicolumn{8}{|l|}{ Diagnosis } & \multirow[b]{2}{*}{$\begin{array}{l}\text { No. of } \\
\text { visits }\end{array}$} \\
\hline & & & Gonorrhoea & Trichomoniasis & $\begin{array}{l}\text { Phthirus } \\
\text { pubis }\end{array}$ & Scabies & $\begin{array}{l}\text { Genital } \\
\text { Warts }\end{array}$ & Monilia & $\begin{array}{l}\text { Other } \\
\text { minor } \\
\text { conditions }\end{array}$ & $\begin{array}{l}\text { No } \\
\text { abnormality }\end{array}$ & \\
\hline \multirow[t]{2}{*}{ First } & $\begin{array}{l}14 \\
15 \\
16 \\
17 \\
18\end{array}$ & $\begin{array}{r}2 \\
40 \\
36 \\
5 \\
1\end{array}$ & 2 & $\begin{array}{l}9 \\
6 \\
3 \\
1\end{array}$ & $\begin{array}{l}5 \\
2\end{array}$ & 1 & $\begin{array}{l}1 \\
1\end{array}$ & $\begin{array}{l}1 \\
2\end{array}$ & $\begin{array}{l}4 \\
4 \\
1\end{array}$ & $\begin{array}{l}2 \\
23 \\
21 \\
2\end{array}$ & \multirow[t]{2}{*}{404} \\
\hline & Total & 84 & 2 & 19 & 7 & 1 & 2 & 3 & 9 & 48 & \\
\hline \multirow[t]{2}{*}{ Second } & $\begin{array}{l}14 \\
15 \\
16 \\
17 \\
18\end{array}$ & $\begin{array}{r}11 \\
17 \\
15 \\
3\end{array}$ & $\begin{array}{l}2 \\
1 \\
(1)\end{array}$ & $\begin{array}{l}3 \\
2 \\
5 \\
1\end{array}$ & 2 & & $\begin{array}{l}1 \\
1\end{array}$ & 1 & $\begin{array}{l}1 \\
2\end{array}$ & $\begin{array}{r}5 \\
12 \\
7 \\
2\end{array}$ & \multirow[t]{2}{*}{211} \\
\hline & Total & 46 & $3(1)$ & 11 & 2 & 0 & 2 & 1 & 3 & 26 & \\
\hline \multirow[t]{2}{*}{ Third } & $\begin{array}{l}14 \\
15 \\
16 \\
17 \\
18\end{array}$ & $\begin{array}{l}2 \\
7 \\
6 \\
3\end{array}$ & $2^{1}$ & $\begin{array}{l}1 \\
1 \\
2 \\
2\end{array}$ & & & 2 & & 1 & $\begin{array}{l}1 \\
6 \\
2 \\
1\end{array}$ & \multirow[t]{2}{*}{77} \\
\hline & Total & 18 & $3(1)$ & 6 & $\mathbf{0}$ & 0 & 2 & 0 & 1 & 10 & \\
\hline \multirow[t]{2}{*}{ Fourth } & $\begin{array}{l}14 \\
15 \\
16 \\
17 \\
18\end{array}$ & $\begin{array}{l}1 \\
2 \\
4\end{array}$ & $\begin{array}{l}1 \\
\text { (1) }\end{array}$ & 2 & & & & & 2 & 2 & \multirow[t]{2}{*}{47} \\
\hline & Total & 7 & $1(1)$ & 2 & 0 & $\mathbf{0}$ & $\mathbf{0}$ & $\mathbf{0}$ & 2 & 2 & \\
\hline \multirow[t]{2}{*}{ Fifth } & $\begin{array}{l}14 \\
15 \\
16 \\
17 \\
18\end{array}$ & $\begin{array}{l}1 \\
1\end{array}$ & & 1 & & & & & & 1 & \multirow[t]{2}{*}{10} \\
\hline & Total & 2 & 0 & 1 & 0 & 0 & 0 & 0 & 0 & 1 & \\
\hline \multirow[t]{2}{*}{ Sixth } & $\begin{array}{l}14 \\
15 \\
16 \\
17 \\
18\end{array}$ & 1 & & & & & & & 1 & & \multirow[t]{2}{*}{1} \\
\hline & Total & 1 & 0 & 0 & 0 & 0 & 0 & 0 & 1 & 0 & \\
\hline Total & & 158 & $9(3)$ & 39 & 9 & 1 & 6 & 4 & 16 & 87 & 750 \\
\hline \multicolumn{12}{|c|}{ 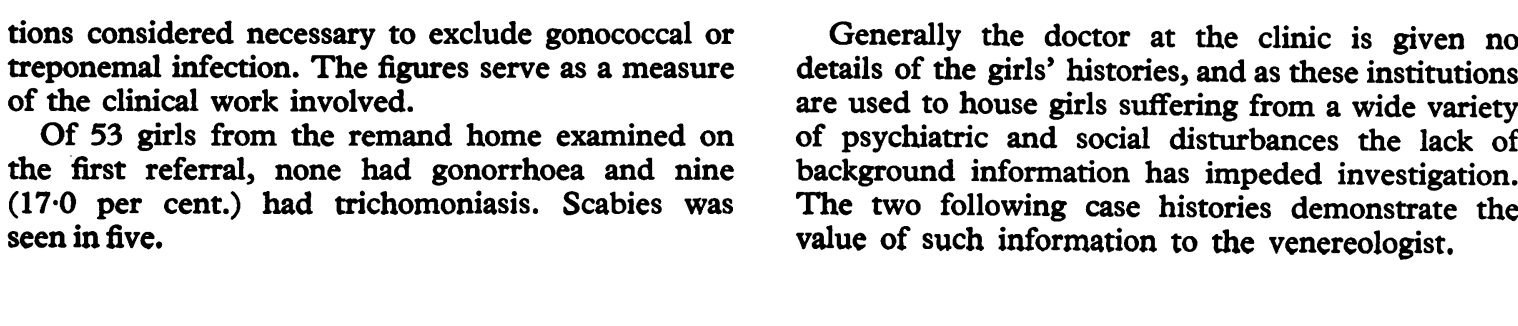 } \\
\hline
\end{tabular}


TABLE III Results of examinations of girls sent to clinic from approved school C (Fanuary 1964December 1966)

\begin{tabular}{|c|c|c|c|c|c|c|c|c|c|c|c|}
\hline \multirow[b]{2}{*}{$\begin{array}{l}\text { Admission } \\
\text { to clinic }\end{array}$} & \multirow[b]{2}{*}{$\begin{array}{l}\text { Age } \\
\text { (yrs) }\end{array}$} & \multirow[b]{2}{*}{$\begin{array}{l}\text { No. of } \\
\text { girls }\end{array}$} & \multicolumn{8}{|l|}{ Diagnosis } & \multirow{2}{*}{$\begin{array}{l}\text { No. of } \\
\text { visits }\end{array}$} \\
\hline & & & Gonorrhoea & Trichomoniasis & $\begin{array}{l}\text { Phthirus } \\
\text { pubis }\end{array}$ & Scabies & $\begin{array}{l}\text { Genital } \\
\text { warts }\end{array}$ & Monilia & $\begin{array}{l}\text { Other } \\
\text { minor } \\
\text { conditions }\end{array}$ & $\begin{array}{l}\text { No } \\
\text { abnormality }\end{array}$ & \\
\hline \multirow[t]{2}{*}{ First } & $\begin{array}{l}14 \\
15 \\
16 \\
17 \\
18\end{array}$ & $\begin{array}{r}3 \\
6 \\
13 \\
3 \\
1\end{array}$ & (1) & $\begin{array}{l}2 \\
4 \\
1\end{array}$ & $\begin{array}{l}1 \\
1\end{array}$ & & 1 & & $\begin{array}{l}2 \\
2 \\
1\end{array}$ & $\begin{array}{l}1 \\
4 \\
6 \\
1\end{array}$ & 99 \\
\hline & Total & 26 & (1) & 7 & 2 & 0 & 1 & 0 & 5 & 12 & \\
\hline \multirow[t]{2}{*}{ Second } & $\begin{array}{l}14 \\
15 \\
16 \\
17 \\
18\end{array}$ & $\begin{array}{l}3 \\
3 \\
2\end{array}$ & 1 & 1 & & & & & & $\begin{array}{l}3 \\
2 \\
1\end{array}$ & 31 \\
\hline & Total & 8 & 1 & 1 & 0 & 0 & 0 & 0 & 0 & 6 & \\
\hline Total & & 34 & $1(1)$ & 8 & 2 & 0 & 1 & 0 & 5 & 18 & 130 \\
\hline
\end{tabular}

In col. 1 the number refers to the admission to the clinic register as a new case on first admission or as a re-admission after recall to school after absconding, etc.

The bracketed figure in col. 4 indicates the number of cases of gonorrhoea diagnosed on microscopy alone. The unbracketed figure refers to cases proved by culture.

The last column shows the total number of visits to the clinic.

TABLE IV Results of examinations of girls sent to clinic from remand home (1965)

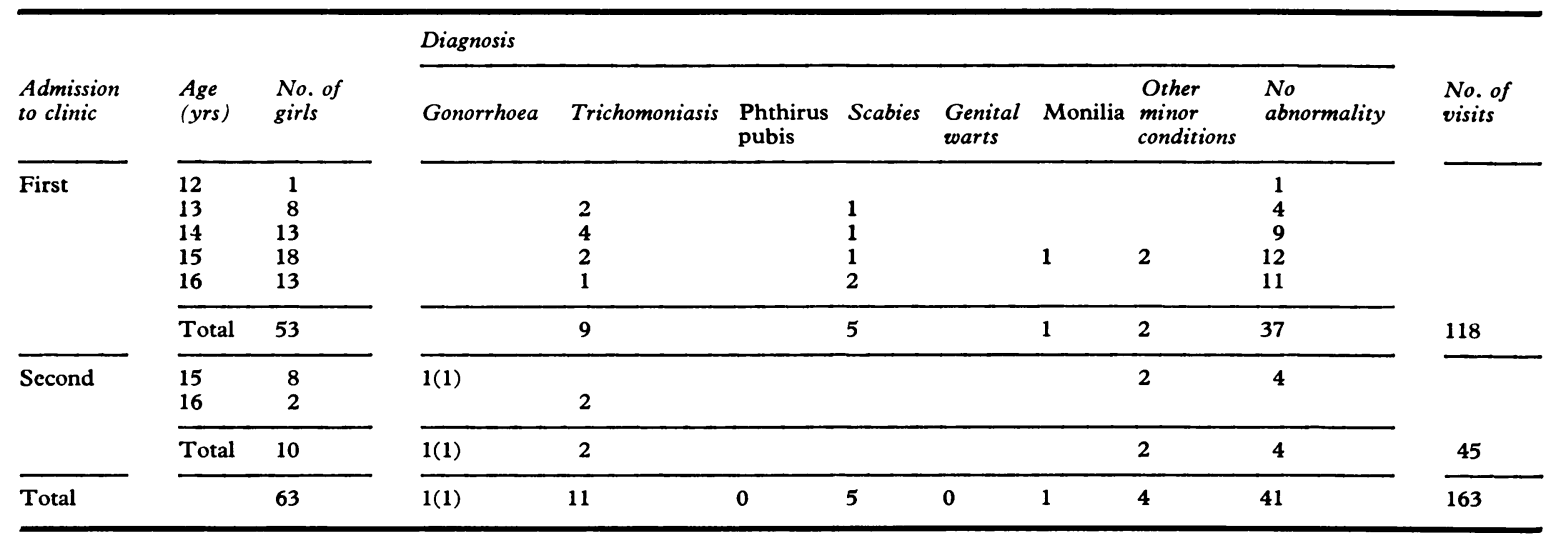

In col. 1 the number refers to the admission to the clinic register as a new case on first admission or as a re-admission after recall to school after absconding, etc.

The bracketed figure in col. 4 indicates the number of cases of gonorrhoea diagnosed on microscopy alone. The unbracketed figure refers to cases proved by culture.

The last column shows the total number of visits to the clinic.

Case 1, a girl aged 15 years 7 months, was brought to the court by an Inspector of the Royal Scottish Society for the Prevention of Cruelty to Children, who requested authorization to 'remove and detain the said young person' at the Remand Home. Her father had deserted the family and her mother could not control her. In June, 1967, she stayed out all night and said she had been 'on the beach'. Two months later she was traced by the police after being missing for 2 days. She had become drunk and hysterical at an all-night party and the police surgeon discovered that she had had frequent sexual intercourse.
The following New Year's Eve she again went off for 2 days and would not say where she had been. A month later she disappeared for 24 hours and was found lying in the street intoxicated. She again refused to say where she had been.

The following evening, having been forbidden by her mother to leave the house, she climbed out of her bedroom window, but returned later the same night. A week later she was given a $£ 1$ note by her mother to run an errand, and did not return until traced by the police, who knew 
that she was associating with convicted criminals and had been seen taking drugs.

Comment on first medical examination at the clinic (February 2, 1968)

Uncooperative and agitated. Intercourse denied. Physical condition consistent with regular intercourse. $T$. vaginalis vaginitis noted.

Case 2, a girl aged 15, was brought to the court by a children's officer, who requested permission to detain her at a Remand Home. Since her parents had been divorced in 1966, she had resided with her mother at various addresses, but was reported missing to the police in March, 1967, and was found to be living with friends. She refused to return home, stating that she did not get on with her mother; it was ascertained that she had not attended school since the previous November.

When interviewed by the R.S.S.P.C.C. Inspector and the children's officer, she stated that she would rather stay with either of her grandparents than with her mother. In April, 1967, it was reported that she had gone to live with her maternal grandmother and was attending school.

In August, however, she was living with her father and was again reported missing to the police.

In September it was learned that she was due to appear before a Juvenile Court on a charge of petty theft. She absconded before she could be brought to court, and was placed under police supervision, but her mother complained that she was beyond her control. The children's officer felt that she was in moral danger and therefore wished her to be placed in a remand home for her own protection.

Comment on first medical examination at clinic Apprehensive, denied intercourse, difficult to examine. Physical condition consistent with her denial of intercourse.

\section{Discussion}

Among the girls from approved schools examined on first referral to the clinic, about 2 per cent. had gonorrhoea and a much higher proportion (23.6 per cent.) had vaginal trichomoniasis. It is possible that in some cases an infection had already been detected and treated at the assessment stage in a remand home before admission to the approved school. Other sexually-transmitted infections such as venereal warts were also found. With those girls examined again after returning to the school after a period of absence, there was an apparently increasing incidence of gonorrhoea with each successive recall, probably because of the higher proportion of promiscuous girls among habitual absconders. The present system of referring girls from custodial institutions and indeed of all girls under compulsory supervision requires improvement. Though the venereologist may deal with only a segment of a girl's problem, it is important to ensure that he is given a social and medical history on her first atten $-\frac{7}{0}$ dance at the clinic; any tendency to make referral $\frac{C}{O}$ into a compulsory routine becomes distasteful, and $\overline{\bar{\omega}}$. care is required to ensure that each girl is considered $\vec{\Phi}$ individually. It may be difficult or inappropriate to provide facilities at a school or remand home for an initial examination to determine presumptive vir- $\overrightarrow{0}$ ginity or to decide whether a full examination is $\overrightarrow{-}$ necessary for the exclusion of sexually-transmitted $\vec{\sigma}^{\circ}$ disease. If a girl has to be referred to a venereologisto for such a preliminary examination adequate social ${ }_{+}$. and medical particulars of the individual case must? be provided.

When girls are brought into custodial institutions $\overrightarrow{\text { के }}$

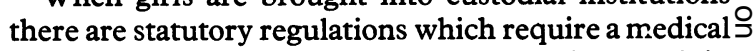
examination within 24 hours of admission, and in particular the Remand Home Rules, applicable to $\$$ England and Wales (see Appendix), require also an examination for the exclusion of venereal disease 'where reason exists to suspect its occurrence'. In the individual case it may be important to examine a $\vec{e}$ girl as soon as possible, but to apply the rule as a. routine to all girls soon after arrival in a strange institution may be psychologically traumatic. In dealing with the persistently promiscuous girl, there is also a particular medical problem to ensure that she remains free from sexually-transmitted $\frac{\odot}{\varnothing}$ infection. Only her retention in a closed institution $\stackrel{2}{\Rightarrow}$ can ensure this, and if she is allowed a degree of freedom she must be encouraged to attend a clinic near her own home. Such girls require this continuous? follow-up after release from custody, and everything should be done to gain their confidence and persuade? them to seek help if they need it. Otherwise they may을 become members of the pool of infection, particularly. of gonorrhoea, which exists in the community. Such examination and follow-up will also be advisable for many girls dealt with by the courts, whatever 음 decision is made regarding their disposal; it should $D$ not be thought that only those reaching institutions? require this aspect of medical care.

As the gonococcus is capricious in culture and as repeated negative smears and cultures are required 0 to exclude infection in the female, numerous follow- $-\mathrm{N}$ up examinations have been undertaken in the series of girls discussed in this paper. The large amounto of work entailed by a very small number of girls is $\Phi$ shown in the Tables; 750 gynaecological inves-? tigations, including an examination by speculum, 7 were conducted for an institution with about 33요 places over a period of 38 months (population of $\stackrel{\mathbb{Q}}{\mathscr{Q}}$ School A on March 31, 1967, see Robertson, 1969). $\stackrel{\mathbb{Q}}{\mathscr{Q}}$ Diagnosis of gonorrhoea was generally made at the girl's first admission or on re-admission, and the follow-up examinations were always negative. Any응 
modification of the regime should be directed towards encouraging examination on first admission and on re-admission, and reducing the number of intermediate examinations. Though early syphilis was encountered only once in this series during the last decade, serological tests have been carried out routinely during the 90 days after the last sexual intercourse.

Details of medical duties laid down in statutory regulations (see Appendix) often appear archaic, and though some aspects of care are defined other equally important aspects are omitted. There is considerable variation between institutions in the policy of sending girls for examination, and there is an obvious difficulty in selection. If there is any doubt at all the girl should be examined and the doctor should be informed of her background. Information about venereal disease should not invariably be given to parents as is laid down in the Remand Home Rules (see Appendix relating to England and Wales), since this may cause unnecessary distress.

Legislation is ostensibly directed unselectively at both sexes, but actual or suspected promiscuity is taken much more seriously in girls. With all its euphemisms, there seems to be little change in the new Social Work (Scotland) Act, 1968, which continues to provide for compulsory care; young persons will be brought before a 'panel' at a 'children's hearing' instead of a 'juvenile court', and they may still be detained in segregated communities. 'Remand homes' will not be called by that name and together with 'approved schools' they will become 'residential establishments where education is provided'. The authors question the wisdom of conveying information on virginity and sexually-transmitted infections to the staff of such institutions. The information may be misinterpreted, and may create prejudice against the girl; it is common experience that even those concerned with the welfare of young persons may react abnormally to knowledge of their sexual behaviour (Howard Jones, 1967), for example, by detaining them longer in custody.

The new Act also continues to define 'children' as 'those who are less than 16 years old' or those who are over 16 and under 18 in respect of whom a supervision order is in force (Robertson, 1969). Such legislation makes it possible for a group of girls to be continuously segregated because of sexual behaviour which is not in itself punishable in other persons. It would be a serious matter if a process leading to detention could be initiated by social workers associated with a venereal diseases clinic. A girl aged 17 who was subject to a supervision order might be unwilling to attend a clinic and seek medical treatment for fear of this. Such unwanted effects are always liable to result from legislative definitions dealing with young persons who are maturing physically at a progressively earlier age (Tanner, 1962), and who may be, in Scotland, regarded as mature enough to marry at the age of 16 years without parental sanction.

\section{Summary}

Of 110 girls examined on first referral to a venereologist from approved schools only two $(1.8$ per cent.) had gonorrhoea proven by culture, although it is possible that in some of them an infection had already been detected at the assessment stage in a remand home before admission to the approved school. A further 26 (23.6 per cent.) had vaginal trichomoniasis, nine had phthirus pubis, and three had genital warts. Of 54 re-examined after recall to the school after absconding or after holidays or for other reasons, four ( $7 \cdot 4$ per cent.) had proven gonorrhoea and twelve (22.2 per cent.) trichomoniasis. Of eighteen recallcd a third time, three (16.7 per cent.) had gonorrhoea and six trichomoniasis ( 33.3 per cent.). The apparently increasing incidence of gonorrhoea in those re-admitted to the clinic register is explained by the higher proportion of promiscuous girls among habitual absconders.

The importance is stressed of giving sufficient social and medical information about girls sent to the venereologist for examination, and any tendency to convert this referral into a compulsory routine is deprecated.

Relevant statutory regulations for Scottish and English remand homes and approved schools are quoted for the convenience of practising venereologists. The rule requiring examination for the exclusion of venereal disease within 24 hours of admission is criticised, and methods of improving the system of examination and follow-up of promiscuous girls are suggested.

The wisdom of communicating information about venereal disease to a girl's parents is questioned. It is pointed out that legislative attempts to control promiscuity are aimed at girls rather than boys, and attention is drawn to possible unwanted effects of such regulations.

\section{References}

Jones, H. (1967). 'Crime in a Changing Society', Pelican Book A692, p. 144. Penguin Books, Harmondsworth. RoBertson, D. H. H. (1969). Brit. F. vener. Dis., 45, 129. Tanner, J. M. (1962). 'Growth at Adolescence', 2nd ed. Blackwell, Oxford. 


\section{APPENDIX}

\section{Statutory Regulations relating to Remand Homes and Approved Schools in Scotland and England}

The Rules applying to Medical Officers and matters relevant to venereal disease are given below. It is only in the Remand Home Rules relating to England that venereal diseases are specifically mentioned, where they are $\frac{\overline{\bar{n}}}{2}$ included in the term 'infectious disease'.

\section{Scotland}

(A) REMAND HOME RULES. 1964 NO. 1260 (S.85) CHILDREN AND YOUNG PERSONS, THE REMAND HOME (SCOTLAND) RULES, 1964.

\section{Medical care}

14 (1) The duties of the medical officer shall include:

(a) the general supervision of the health and cleanliness of the children in the remand home;

(b) the general supervision of the hygienic condition of the remand home premises and of the health of the staff;

(c) attendance at the remand home at weekly intervals;

(d) examination of each child within 24 hours of his admission to the remand home;

(e) provision for each child of such medical attention as may be necessary;

$(f)$ examination of each child immediately before his discharge from the remand home unless this is considered unnecessary by the medical officer;

(g) supervision of the compilation of a medical record for each child containing, so far as the circumstances of each case permit or make necessary, particulars of the medical history of the child before admission, his physical and mental condition on admission, his medical history while accommodated in the remand home and his condition on discharge from the remand home; and

(h) the preparation and submission to the local authority of such reports in relation to the duties described in this sub-paragraph as may be required by the local authority.

(2) If a child in the care of a local authority is accommodated in a remand home not under the control of that authority, the authority responsible for the remand home shall on a request which may be made at any time provide that local authority with a medical report on the child.

(B) APPROVED SCHOOL RULES. 1961 NO. 2243 (S.124) CHILDREN AND YOUNG PERSONS, THE APPROVED SCHOOLS (SCOTLAND) RULES, 1961.

37. The parents and the Secretary of State shall be informed immediately of any case of serious illness, infectious disease, accident or death. Except in cases of urgency or where a parent is not accessible, managers shall communicate with parents in any case where there is to be an operation on a pupil involving the use of a general anaesthetic.

40. The Managers shall appoint a Medical Officer whose duties shall include:

(a) a thorough examination of each pupil on admission and shortly before leaving the school; (b) a quarterly inspection of each pupil;

(c) the examination and treatment of pupils as required; $\vec{\circ}$

(d) a visit to the school at least once each week;

(e) general inspection and advice as to dietary and $\vec{\omega}$ general hygiene in the school;

$(f)$ the keeping of such medical records as may be $\stackrel{0}{=}$. required; such records shall be available in the school $\vec{D}$ for examination by the Medical Officer appointed by the Secretary of State for the purpose;

(g) the furnishing of such reports and certificates as the Managers may require; and

(h) the examination of the punishment book at each $\vec{T}$ visit. He shall draw the attention of the Managers $\mathbb{D}$ to any case of excessive punishment.

41. Acting on the advice of the Medical Officer, who $\stackrel{2}{2}$ shall consult the Medical Officer of Health for their area, the Managers shall make full use of the preventive health $\varphi$ measures at their disposal including vaccination, immuni- $\bigcirc$ sation and chest $\mathbf{x}$-ray. They shall have due regard to $\square$ quarantine periods and control measures for infectious disease, as specified by the Medical Officer of Health for their area.

42. Managers shall make suitable arrangements for the $\frac{\mathscr{Q}}{\mathbb{Q}}$

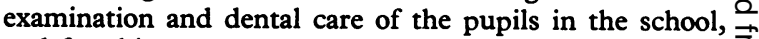
and for this purpose may use the School Health Service 0 or the general dental service provided under the National 3 Health Service (Scotland) Act, 1947 (a), or make such $\rightleftharpoons$ special arrangements as are necessary. Pupils shall be examined on admission and thereafter at least once every of six months. A record shall be kept of examinations and treatment.

Other duties are described in connection with discipline, corporal or other punishment, segregation and employment.

\section{England and Wales}

(A) REMAND HOME RULES. THE REMAND HOME RULES, 1939, S.R. \& O. 1939. NO. 12.

(8) Each boy shall be thoroughly cleaned on admission; N and shall be medically examined by a doctor within $N$ twenty-four hours, or in cases of difficulty within forty- $\omega$ eight hours, after his admission to the remand home, and also, in the case of a boy known to be awaiting removal to $\stackrel{\circ}{C}$ any approved school, within a similar period before $\mathbb{D}$ such removal, and also at any other time or times that $\stackrel{\oplus}{+}$ may be considered necessary by the Medical Officer or $T$ Superintendent. Such examinations shall include any $\overrightarrow{0}$ steps necessary to ascertain whether venereal disease is $\mathbb{D}$ present in cases where reason exists to suspect its occur- $\overrightarrow{\mathbb{D}}$ rence, and may take place either at the remand home or, if the Medical Officer desires it, at a suitable clinic.

(9) Any boy known or suspected to be suffering from an infectious disease in the remand home shall so far as 
practicable be isolated from others; and where such infectious disease occurs in a remand home any boy subsequently admitted shall so far as is practicable be kept separate for the necessary period from those who have been in contact with the disease.

(18) A doctor shall be appointed as Medical Officer at every remand home; and necessary medical treatment shall be given to the boys. The duties of a Medical Officer shall include regular attendance at the remand home, general supervision of the hygienic condition of the premises and of the health of the boys and the suitable provision of medical attention. If it becomes necessary to remove a boy from the remand home to a hospital, clinic or other place of safety for medical treatment or examination, or if the Medical Officer is of the opinion that on medical grounds a boy should not be further detained in the remand home, the Superintendent shall inform the parent of a boy, the council, the clerk of the committing court and also, in the case of a boy committed to custody, in the remand home under Section 54 of the Act, the Secretary of State.

(19) No operative treatment shall be carried out on a boy without the previous consent of his parent or guardian unless either the parent or guardian cannot be found or the condition of the boy is such that any delay would involve unnecessary suffering or injury to health.

(20) The Superintendent shall report at once any death and any case of serious illness, infectious disease, or accident, to the parent of the boy, to the council and to the Chief Inspector. Any violent or sudden death shall be notified immediately to the Coroner of the district.

'Infectious disease' means inter alia venereal disease.

(B) APPROVED SCHOOL RULES. THE APPROVED SCHOOL RULES, 1933, S.R. \&.O. 1933. NO. 774.

44 (1) The Managers shall appoint a Medical Officer, whose duties shall include:

(a) a thorough examination of each boy on admission and shortly before leaving the school;

(b) a quarterly inspection of each boy;

(c) visits to the school at least once a week;

(d) general inspection of the school from the hygienic point of view and advice as to dietary and general hygiene;

(e) the examination and treatment of all sick and ailing boys;

$(f)$ the keeping of medical records in a form approved by the Chief Inspector;

(g) the furnishing of such reports and certificates as the Managers may require.

(2) Notice of any meeting of the Managers shall be given to the Medical Officer.

46. The Headmaster shall report at once any death and any case of serious illness, infectious disease or accident to the parent or guardian of the boy, and to the Chief Inspector.

\section{Commentary on statutory regulations}

As these regulations stand, medical information relating to girls can be demanded in Scotland by the local authority in the case of remand homes, and by managers or by the Secretary of State in the case of approved schools. Paragraph 37 (Approved School Rules) might imply that information about venereal disease can be transmitted to parents.

In England, in the Remand Home Rules, 1939, infectious disease is stated to include inter alia venereal disease, and strict adherence to this rule necessitates the reporting of venereal disease to the parent of the child, to the Council, and to the Chief Inspector. Rule 46 in the Approved School Rules may mean the same.

\section{Problèmes médicaux-légaux dans le traitement des jeunes délinquantes en Ecosse. II. Infections transmises par contacts sexuels chez les filles des institutions de détention}

Deux seulement ( 1,8 pour cent) parmi 110 filles dépendant d'écoles d'éducation surveillée, examinées pour la première fois par un vénéréologue, avaient une gonococcie assurée par culture; il est cependant possible que, chez certaines d'entre elles, l'infection ait été déjà reconnue au cours de leur séjour dans le Foyer de détention où elles attendaient la décision prise à leur égard, avant d'entrer dans l'école d'éducation surveillée. En outre, 26 (23,6 pour cent) avaient une trichomonase, neuf une pédiculose pubienne, et trois des végétations vénériennes. Cinquante quatre furent réexaminées lorsqu'elles furent réadmises à l'école, après une évasion, après les vacances, ou pour toute autre raison. Quatre $(7,4$ pour cent) avaient une gonococcie certaine et douze $(22,2$ pour cent) une trichomonase. Dix-huit furent admises une troisième fois: trois $(16,7$ pour cent) présentaient une gonococcie et six (33,3 pour cent) une trichomonase. L'apparente augmentation de l'incidence de la gonococcie aux examens clini- ques ultérieurs s'explique par la proportion plus élevée de vagabondes sexuelles chez les filles qui s'évadent habituellement de telles institutions. On souligne l'importance de donner des informations sociales et médicales suffisantes sur les filles présentées à l'examen du vénéréologue, et l'on critique toute tendance de transformer cette présentation en routine obligatoire.

Les règlements établis, en Angleterre et en Ecosse, pour les foyers de détention et les écoles d'éducation surveillée le sont pour la commodité des vénéréologues. La règle qui requiert l'examen pour la détection de maladie vénérienne dans les premières vingt-quatre heures de l'admission est critiquée, et l'on suggère des méthodes pour améliorer le système d'examen et de surveillance de ces vagabondes sexuelles.

On se pose la question de l'intérêt de communiquer des informations concernant une maladie vénérienne éventuelle aux parents de la fille.

Il est souligné que les efforts législatifs de lutte contre la promiscuité s'adresse aux filles plutôt qu'aux garçons et l'on attire l'attention sur les effets néfastes possibles de telle réglementation. 